\title{
Biokonversi Sampah Organik dengan Metode Larva Black Solder Fly
}

\author{
Bioconversion of Organic Waste Using Black Solder Fly Larvae Method
}

\section{Sukhriyatun Fitriyah $^{1}$, Eko Maulana Syaputra ${ }^{2}$}

\author{
${ }^{1}$ Program Studi Kesehatan Masyarakat, Universitas Wiralodra, Indramayu \\ ${ }^{2}$ Program Studi Kesehatan Masyarakat, Universitas Wiralodra, Indramayu \\ e-mail: sukhriyatunfitriyah@gmail.com ${ }^{1}$, ekomaulanasyaputra@unwir.ac.id ${ }^{2}$
}

\begin{abstract}
Abstrak
Manusia memiliki interaksi yang sangat kuat dengan lingkungan serta didalam kehidupannya selalu bergantung dengan alam atau lingkungan sekitarnya. tahun 2017 Indonesia diperkirakan menghasilkan 64 juta ton sampah setiap tahun. komposisi sampah didominasi oleh sampah organik, yakni mencapai $60 \%$ dari total sampah. Larva BSF merupakan strategi inovatif dan salah satu metode berkelanjutan untuk pengelolaan sampah organik. Dari latar belakang yang telah diuraikan, penelitian ini bertujuan untuk untuk menganalisis larva black soldier fly dalam mereduksi sampah organik. Analisis penelitian ini dilakukan dengan metode Rancangan Acak Lengkap (RAL). Sampel telur larva sebanyak 8 gram. Perlakuan dilakukan selama 21 hari dengan pemberian sampah sayur dan buah sebanyak $2,5 \mathrm{~kg}$ setiap dua hari sekali. Hasil penelitian menunjukkan bahwa Perhitungan rata-rata berat akhir larva BSF usia 21 hari sebesar 0.25 gram. Pertambahan berat larva setiap dua hari nya rata-rata 0,02 gr - 0,03 gr. Pada 7 hari pertama setelah penetasan, berat larva sebesar $0.02 \mathrm{gr}$ hal ini dikarenakan kemampuan larva dalam mereduksi sampah masih rendah. Usia di atas 7 hari kemampuan larva dalam mereduksi sampah sangat cepat dimana penambahan berat rata-rata larva sebesar $0.03 \mathrm{gr}$. Hasil akhir pengukuran panjang larva sebesar $0.8 \mathrm{~cm}$. Penambahan panjang larva paling besar di hari $1-3$ hari dari $0 \mathrm{~cm}-2 \mathrm{~cm}$, kemudian penambahan panjang maggot bertambah $0.1 \mathrm{~cm}$ per 2-4 hari selama 21 hari perlakuan. Hasil penelitian ini menunjukkan bahwa kemampuan larva dalam mereduksi sampah sangat baik.
\end{abstract}

Kata kunci: Biokonversi, sampah organik, larva BSF.

\begin{abstract}
Humans have a very strong interaction with the environment and in their lives always depend on nature or the surrounding environment. In 2017, Indonesia is estimated to produce 64 million tons of waste every year. the composition of waste is dominated by organic waste, which reaches $60 \%$ of the total waste. BSF larvae are an innovative strategy and one of the sustainable methods for organic waste management. From the background that has been described, this study aims to analyze the black soldier fly larvae in reducing organic waste. The analysis of this research was using Completely Randomized Design (CRD). Samples of larvae eggs as much as 8 grams. The treatment was carried out for 21 days by giving $2.5 \mathrm{~kg}$ of vegetable and fruit waste every two days. The results showed that the average final weight of 21 -day-old BSF larvae was 0.25 grams. The average weight gain of larvae every two days is $0.02 \mathrm{gr}-0.03 \mathrm{gr}$. In the first 7 days after hatching, the weight of the larvae is $0.02 \mathrm{~g}$. This is because the ability of the larvae to reduce waste is still low. Age above 7 days the ability of larvae to reduce waste is very fast where the average weight gain of larvae is $0.03 \mathrm{gr}$. The final result of measuring the length of the larvae is $0.8 \mathrm{~cm}$. The largest addition of larval length was on 1-3 days from 0 $\mathrm{cm}-2 \mathrm{~cm}$, then the addition of maggot length increased $0.1 \mathrm{~cm}$ per 2-4 days for 21 days of treatment. The results of this study indicate that the ability of larvae in reducing waste is very good.
\end{abstract}

Keywords: Bioconversion, organic waste, BSF larvae.

\section{Pendahuluan}

Berdasarkan data Kementerian Lingkungan Hidup dan Kehutanan (KLHK) tahun 2017 Indonesia diperkirakan menghasilkan 64 juta ton sampah setiap tahun. komposisi sampah didominasi oleh sampah organik, yakni mencapai $60 \%$ dari total sampah. Sampah plastik menempati posisi kedua dengan 14\% disusul sampah kertas 9\% dan karet 5,5\%. Sampah lainnya terdiri atas logam, kain, kaca, dan jenis sampah lainnya. ${ }^{1}$ Larva Black Soldier Fly (BSF) dapat dimanfaatkan untuk mengkonversi materi organik sehingga memiliki potensi ekonomi. ${ }^{2}$ Karena larva BSF mampu mendegradasi sampah 
organik, baik sampah yang berasal dari hewan maupun tumbuhan. Kemampuan mendegradasi sampah larva BSF dilaporkan lebih baik dibanding serangga lainnya. ${ }^{3}$ Tujuan penelitian ini untuk menganalisis larva black soldier fly dalam mereduksi sampah organik.

Larva BSF memiliki klasifikasi taksonomi sebagai berikut:

Nama umum : Black Soldier Fly, American Soldier Fly, Tentara Hitam

Kingdom : Animalia

Filum : Arthropoda

Kelas : Insecta

Ordo : Diptera

Sub ordo : Brachycera

Super family : Stratiomyoidea

Famili : Stratiomyidae

Genus : : Hermetia

Spesies : :Hermetia illucens. ${ }^{4}$

Morfologi dan Siklus Hidup Lalat Black Soldier Fly (Hermetia illucens)

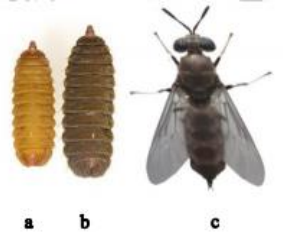

Gambar 1. (a) Larva, (b) Pupa dan (c) Lalat dewasa BSF. ${ }^{5}$

Lalat Black Soldier Fly (BSF) atau yang sering dikenal dengan lalat tentara hitam memiliki tubuh yang sesuai dengan julukan yaitu berwarna hitam dan pada bagian abdomen lalat ini berwarna transparan (wasp waist) sehingga sekilas menyerupai warna abdomen lebah. Panjang tubuh lalat ini berkisar 15-20 mm dan jangka hidupnya hanya 3-5 hari.

Lalat $H$. illucen merupakan insekta yang berasal berasal dari Amerika serikat dan kemudian tersebar ke wilayah tropis dan subtropis didunia. Indonesia merupakan Negara yang memiliki iklim tropis sehingga kondisi ini sangat ideal untuk budidaya $H$. illucen. Lalat ini sangat mudah dikembangkan dalam skala massal dan tidak memerlukan peralatan yang khusus. Tahap akhir larva (pupa) akan bermigrasi sendiri dari media tumbuh yang digunakan, sehingga memudahkan untuk dipanen. Lalat bukan lalat hama dan tidak ditemukan di tempat yang kotor atau padat penduduk sehingga lalat ini relative aman dilihat dari segi kesehatan manusia. ${ }^{6}$

Belakangan ini ditemukan kegiatan daur ulang sampah organik dengan metode biokonversi. Newton et al. mendefinisikan biokonversi sebagai perombakan sampah organik menjadi sumber energi metan melalui proses fermentasi yang melibatkan organisme hidup. ${ }^{7}$ Sampah adalah sisa kegiatan sehari-hari manusia dan/atau proses alam yang berbentuk padat. Sampah adalah sisa kegiatan sehari hari manusia atau proses alam yang berbentuk padat atau semi padat berupa zat organik atau anorganik bersifat dapat terurai atau tidak dapat terurai yang dianggap sudah tidak berguna lagi dan dibuang kelingkungan. ${ }^{8}$

Pengelolaan sampah secara ideal dilakukan melalui pendekatan proses bersih dan dikembangkan menjadi konsep hierarki. Urutan prioritas penanganan limbah secara umum, yaitu:

Langkah 1 Reduce (pembatasan): mengupayakan agar limbah yang dihasilkan sesedikit mungkin, langkah 2 Reuse (guna-ulang): bila limbah akhirnya terbentuk, maka upayakan memanfaatkan limbah tersebut secara langsung, langkah 3 Recycle (daur-ulang): residu atau limbah yang tersisa atau tidak dapat dimanfaatkan secara langsung, kemudian diproses atau diolah untuk dapat 
dimanfaatkan, baik sebagai bahan baku maupun sebagai sumber enersi, langkah 4 treatment (olah): residu yang dihasilkan atau yang tidak dapat dimanfaatkan kemudian diolah, agar memudahkan penanganan berikutnya, atau agar dapat secara aman dilepas ke lingkungan, langkah 5 Dispose (singkir): residu/limbah yang tidak dapat diolah perlu dilepas ke lingkungan secara aman, yaitu melalui rekayasa yang baik dan aman seperti menyingkirkan pada sebuah lahan-urug (landfill) yang dirancang dan disiapkan secara baik, langkah 6 Remediasi: media lingkungan (khusunya media air dan tanah) yang sudah tercemar akibat limbah yang tidak terkelola secara baik, perlu direhabilitasi atau diperbaiki melalui upaya rekayasa yang sesuai, seperti bioremediasi dan sebagainya. ${ }^{9}$ Tujuan penelitian ini yaitu untuk menganalisis larva black soldier fly dalam mereduksi sampah organik

\section{Metode Penelitian}

Lokasi penelitian dilakukan di Bank Sampah Amiraa Desa Singaraja. Penelitian dilakukan selama bulan November 2021. Penelitian ini menggunakan metode Rancangan Acak Lengkap (RAL) dimana percobaan dilakukan sederhana dengan secara acak pada unit percobaan dengan satu taraf perlakuan yaitu perlakuan menggunakan sampah organik jenis sayuran dan buah-buahan. Penelitian ini bertujuan untuk mengetahui pengaruh jenis media pertumbuhan maggot, dengan parameter yang diamati yaitu biomassa larva (Berat dan Panjang larva BSF). Teknik pengukuran berat menggunakan timbangan digital dengan satuan gram, sedangkan pengukuran panjang menggunakan alat penggaris mistar $150 \mathrm{~cm}$. Penelitian ini menggunakan telor BSF sebanyak 8 gram di mulai dari pertama menetas hingga menjadi prepupa yaitu selama 21 hari. Jumlah sampah organik sebanyak $10 \mathrm{~kg}$.

\section{Hasil}

Pada penelitian ini ada beberapa yang diamati saat pemanfaatan larva Black Soldier Fly (BSF) terhadap sampah organik yaitu berat dan ukuran satuan larva dan jumlah berat larva BSF. Untuk berat larva Black Soldier Fly (BSF) selama 21 hari serta diukur setiap dua hari dan disajikan pada tabel dibawah ini.

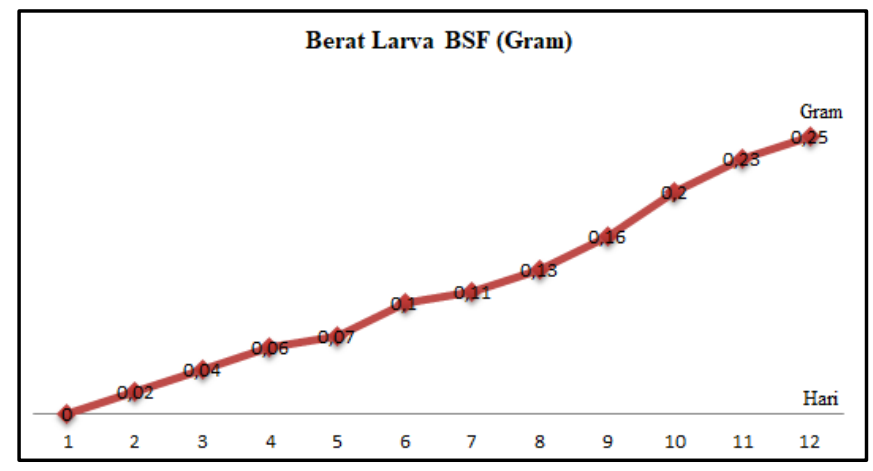

Gambar 1. Berat Rata-rata Larva BSF

Perhitungan rata-rata berat larva BSF bertambah 0,02 gr - 0,03 gr selama 21 hari perlakuan. Pada 7 hari pertama setelah penetasan, berat larva sebesar 0.02 gr hal ini dikarenakan kemampuan larva dalam mereduksi sampah masih rendah. Larva di usia 7 - 20 hari kemampuan larva dalam mereduksi sampah sangat cepat dimana penambaha berat rata-rata larva sebesar 0.03 gr. 


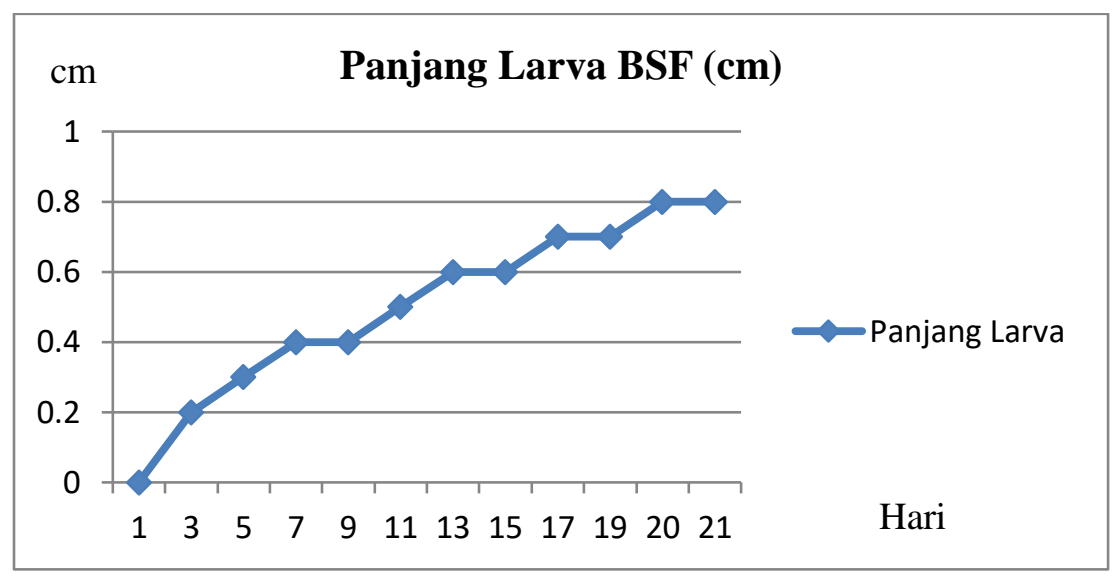

Gambar 2. Rata-rata Panjang Larva BSF

Penambahan panjang larva paling besar di hari 1-3 hari dari $0 \mathrm{~cm}-2 \mathrm{~cm}$, kemudian penambahan panjang maggot bertambah $0.1 \mathrm{~cm}$ per 2-4 hari selama 21 hari perlakuan. Maksimal panjang larva BSF sebesar $0.8 \mathrm{~cm}$.

\section{Pembahasan}

Kegiatan biokonversi sampah menggunakan larva BSF meliputi proses penetasan telur BSF menjadi baby larva sehingga siap diaplikasikan untuk memakan sampah organik, proses pengolahan sampah menggunakan maggot. Proses penetasan telur langsung diaplikasikan pada sampah organik sayur. Percobaan ini berlangsung selama 21 hari dari tanggal 04-25 November 2021. Jumlah berat sampah dan larva pada penelitian ini menggunakan perbandingan 8 gram larva dengan pemberian pakan sebanyak $10 \mathrm{~kg}$ sampah. Penambahan berat larva dilakukan pengukuran setiap dua hari, dengan peningkatan 0.02 gram hinggal maksimal 0.03 gram. Pengaruh penambahan berat larva bergantung banyak dan jenis sampah yang dijadikan pakan larva BSF. Perhitungan akhir di hari ke 21, pada hari ke 21 berat rata-rata larva BSF sebesar 0.25 gram. Pengukuran panjang larva BSF dilakukan bersamaan dengan pengukuran berat larva yaitu setiap dua hari sekali dengan rata-rata penambahan panjang larva sebesar $0.01 \mathrm{~cm}$. penambahan biomassa larva terlihat signifikan diusia 3 hari pertama hal ini dikarenakan media penetasan menggunakan sampah organic berupa sayur. Pada akhir perlakuan larva mencapai berat $0.08 \mathrm{~cm}$.

Larva Black Soldier Fly $(B S F)$ terhadap sampah organik oleh peneliti diteliti selama dua puluh satu hari, dikarenakan. masa konsumsi maggot ini adalah selama dua puluh satu hari yang kemudian berubah menjadi prepupa. Penambahan berat larva dan panjang larva dipengaruhi jumlah banyak sampah yang di berikan, karena pemberian sampah dilakukan tanpa proses mencacah sampah terlebih dahulu, sehingga masih terdapat sisa-sisa sampah yang tidak maksimal untuk diuraikan. Penambahan berat larva dapat berbeda-beda tergantung jenis sampah yang diberikan. Hasil penelitian Putra menunjukkan hasil maggot pengurai sampah sayuran meningkat sebanyak 50 gram menjadi 150 gram dari berat awal 100 gram. Dengan demikian bisa disimpulkan bahwa dengan 100 gram maggot mampu mengurai sampah organik dari jenis sayur, buah serta daging sebanyak 250 gram dengan waktu 7 hari ( 1 minggu). ${ }^{10}$

Dalam 21 hari dari 8 gram maggot dapat mereduksi sampah sebanyak $10 \mathrm{~kg}$. Hal ini dapat disimpulkan bahwa larva BSF dapat dimanfaatkan dalam pengolahan sampah organik. Hal ini didukung oleh penelitian Yuniarti bahwa ketika larva sedang makan, dimana mereka lebih aktif dan lebih banyak berada di bagian yang miskin cahaya. Dalam kondisi ideal larva BSF akan mencapai 
fase prepupa dan ukuran maksimum pada hari ke-21 setelah menetas, Proses metamorfosis pupa menjadi BSF dewasa berlangsung dalam kurun waktu antara sepuluh hari sampai dengan beberapa bulan tergantung kondisi suhu lingkungan. ${ }^{11}$

BSF telah diteliti dapat mendegradasi sampah organik dengan memanfaatkan larvanya yang akan mengekstrak energi dan nutrien dari sampah sayuran, sisa makanan, bangkai hewan, dan kotoran sebagai bahan makanannya. Hal ini sesuai dengan pendapat Holmes menyatakan larva BSF dapat mendegradasi baik sampah padat maupun sampah cair. Selain itu larva BSF mudah untuk dikembangbiakkan dengan sifatnya yang tidak berpengaruh terhadap musim, meskipun lebih aktif pada kondisi yang hangat. ${ }^{12}$ Larva BSF mampu mendegradasi sampai dengan $80 \%$ jumlah sampah organik yang diberikan. ${ }^{2}$ Larva BSF mampu mengkonsumsi sampah makanan dalam jumlah besar lebih cepat dan lebih efisien dibandingkan spesies lain yang diketahui. Hal ini dipengaruhi oleh bagian mulutnya dan enzim pencernaannya yang lebih aktif. Oleh karena itu pemanfaatan larva BSF sangat berpengaruh terhadap sampah organik bukan hanya dapat dihasilkan sebuah kompos, ternyata juga dapat dimanfaatkan sebagai media hidup larva lalat tentara yang selama ini masih sering dipandang tidak bermanfaat dan menjadi perantara penyakit, yang pada akhirnya larva tersebut dijadikan sebuah pakan ternak yang memiliki nutrisi sangat tinggi

\section{Kesimpulan}

Berdasarkan penelitian yang dilakukan mengenai pemanfaatan larva BSF sebagai salah satu upaya pengurangan sampah organic menggunakan maggot, diperoleh beberapa kesimpulan sebagai berikut:

1. Biomassa berat larva BSF selama 21 hari rata-rata sebesar 0.25 gram

2. Biomassa panjang larva $\mathrm{BSF}$ selama 21 hari rata-rata $0.8 \mathrm{~cm}$.

\section{Saran}

Saran dari penelitian ini yaitu Sampah organik sebaiknya dipilah terlebih dahulu tidak dicampur dengan sampah non organik. Pemilahan sampah ini dapat dilakukan minimal di skala rumah tangga. Untuk mengelola dan mengurangi jumlah sampah organik dapat menggunakan larva BSF, karena larva BSF mampu secara cepat dalam mengurai sampah organik.

\section{Daftar Pustaka}

1. KLHK (Kementerian Lingkungan Hidup dan Kehutanan). 2015. Rangkaian Hari Lingkungan Hidup 2015-Dialog Penanganan Sampah Plastik http://kanalkomunikasi.pskl.menlhk.go.id/. Diakses 17 Oktober 2020

2. Diener, S., M. Nandayure, S. Solano, F. R. Gutiérrez, C. Zurbrügg, dan K. Tockner, 2011a. Biological Treatment Of Municipal Organic Waste Using Black Soldier Fly Larvae. Waste Biomass Valor 2,:357-63.

3. Kim, W., et all. 2010. The Larval Age And Mouth Morphology Of The Black Soldier Fly, Hermetia Illucens (Diptera: Stratiomyidae). Int J Indust Entomol 21 (2), : 185-187.

4. Wardhana, April Hari. 2016. Black Soldier Fly (Hermetia illucens) sebagai Sumber Protein Alternatif untuk Pakan Ternak. Wartazoa Vol. 26 No. 2 Hlm. 069-078

5. McShaffrey D. 2013. Hermetia illucens-Black Soldier Fly Hermetia illucens. Bugguide.net [internet]. [cited 31 May 2016]. Available from: http: bugguide.net/node/ view/874940/bimage

6. Li Q, et all. 2011. Bioconversion Of Dairy Manure By Black Soldier Fly (Diptera: Stratiomyidae) For Biodiesel And Sugar Production. Waste Manag. 31:1316-1320. 
7. Newton L, Sheppard C, Watson DW, Burtle G, Dove R. 2005. Using the black soldier fly, Hermetia illucens, as a value-added tool for the management of swine manure. Report for The Animal and Poultry waste Management Center. North Carolina. North Carolina State University Raleigh.

8. Undang-undang No 18 tahun 2008 Tentang Pengelolaan Sampah. www.menlh.go.id.

9. Damanhuri, Enri dan Dr. Tri Padmi. Diktat Sampah. 2010. http://www.kuliah.ftsl.itb.ac.id.

10. Putra, Yongki dan Ade Ariesmayana. 2020. Efektifitas Penguraian Sampah Organik Menggunakan Maggot (Bsf) Di Pasar Rau Trade Center. Jurnalis Vol. 3 No. 1 hal: 1-24

11. Prety Yuniarti ES. 2015. "Pemanfaatan Larva Black Soldier Fly (Hermetia Illucens) Sebagai Salah Satu Teknologi Reduksi Sampah Di Daerah Perkotaan” Fakultas Teknik Sipil Dan Perencanaan. Institut Teknologi Sepuluh November. Surabaya

12. Holmes, L.A., Vanlaerhoven, S.L., Tomberlin, J.K. 2012. Relative Humidity Effects on the Life History of Hermetia illucens (Diptera: Stratiomyidae). Environmental Entomology, 41(4): 971978 